\title{
O CONSUMO COMO POSSIBILIDADE DE AUTONOMIA
}

\section{DANTAS, Sérgio Silva. De refém a protagonista: consumo, identidade e emancipação. Curitiba: CRV, 2015.}

\section{Maria Beatriz Portelinha}

Escola Superior de Propaganda e Marketing, São Paulo, Brasil.

Mestranda do Programa de Pós-graduação em Comunicação e Práticas do Consumo da Escola Superior de Propaganda e Marketing de São Paulo

E-mail: b.portelinha@gmail.com

Na obra De refém a protagonista: consumo, identidade e emancipação, Sérgio Silva Dantas (2015) discute acerca do consumo nas trajetórias de vida e sobre como este assume um papel importante na construção de identidades. Durante a obra, o autor articula as temáticas consumo, identidades e classe social, abrangendo as complexidades disso decorrentes. A partir de uma ampla gama de leituras, utilizando-se de autores da comunicação e da psicologia social, Dantas cria uma fundamentação teórica que nos permite entender sua obra tanto como pesquisadores quanto como indivíduos que se reconstroem e se reconfiguram constantemente.

O livro está organizado em nove capítulos, divididos em três partes: "Consumo", "Identidade" e "Delineamentos da pesquisa". Por ser uma derivação de sua tese de doutorado em psicologia social, Dantas desenvolve o conteúdo em uma sequência semelhante à de trabalhos acadêmicos, reservando os capítulos iniciais para apresentar os pilares centrais de seu estudo (consumo e identidade) e a parte final para a apresentação de discussão da pesquisa realizada e análise e explanação dos resultados.

Na primeira parte de seu trabalho, o autor defende o consumo como parte do sistema cultural, do ponto de vista em que consumir é um ato constante na vida das pessoas. Para Dantas (2015, p. 24), os atos de consumo "têm uma pretensão identitária envolvida", a partir do que as diferentes práticas de consumo adotadas pelos indivíduos resultam em diferentes construções identitárias. O consumo aqui aparece como uma oportunidade a ser abraçada, proporcionando autonomia aos consumidores e possibilitando que contornem condições de vida inerentes ao sistema em que se inserem. $\mathrm{O}$ autor argumenta que o consumo possui um caráter aspiracional, a partir do qual os indivíduos podem, por exemplo, contornar as desigualdades de classe por meio dos produtos que consomem. $\mathrm{O}$ ato de consumir mesclase com o ato de ser cidadão, sendo que muitas vezes é ao consumo que os indivíduos recorrem para entender seu lugar de pertencimento e sua posição na sociedade. Nas palavras do autor,

é o jovem pobre que consome tênis de marca para parecer menos pobre, é a empregada doméstica que tem um celular semelhante ao da patroa para se sentir menos inferiorizada, é a mulher rica que compra a bolsa cara para mostrar status e elegância aos demais, é a pessoa que frequenta 
determinados eventos culturais (peças de teatro, óperas, concertos) e com isso ganha a alcunha de cult, é o indivíduo que viaja para determinados destinos turísticos para ser reconhecido como "chique".

(DANTAS, 2015, p. 24)

Na segunda parte do livro, ao abordar a questão das identidades, Dantas defende o entendimento do consumo como uma prática cultural e social, segundo a qual os hábitos e práticas dos indivíduos dialogam com a construção de suas identidades. O sujeito é pensado no contexto pós-moderno, fragmentado, e assumindo diversas composições e recomposições de identidade frente à intensa dinâmica social. O consumo, nesse contexto, age como uma ferramenta de composição dessas identidades, através do que legitimam e materializam suas crenças, se posicionando perante a sociedade. A identidade é entendida como um processo fluido, em que os sujeitos articulam experiências pessoais e, a partir disso, reformulam a constituição do seu Eu.

Na terceira parte, Dantas apresenta os delineamentos e comenta os resultados da pesquisa, que teve como objetivo geral entender se 0 consumo dos indivíduos viabilizou emancipação em seus projetos de vida. Pensando acerca da identidade, o autor não explora a maneira como os indivíduos são vistos pelos outros, mas se propõe a analisar as identidades de cada um de seus entrevistados e os modos como eles as constroem e continuam reconstruindo.

Para isso, o autor empregou a abordagem qualitativa com uso da técnica de "história de vida", a partir do que pediu a entrevistados que falassem sobre suas trajetórias, para, na análise, verificar "como o sujeito chegou onde está, que caminho percorreu e como, para concretizar seus projetos de vida, ele fez e pretende continuar fazendo uso do consumo" (DANTAS, 2015, p. 124). O caso de uma das entrevistadas

mostra como ela conseguiu, ao libertar-se de políticas de identidade, reverter uma condição de refém do sistema e da sua lógica, construindo uma identidade política e um projeto de vida, no qual soube usar o consumo como um viabilizador de sua emancipação (investir dinheiro em terapia, na viagem para o exterior, nesse novo momento de vida que está vivendo, patrocinado por suas economias anteriores, entre outros, foram consumos emancipatórios). (DANTAS, 2015, p. 165)

A partir da interpretação do material empírico e das reflexões teóricas, o autor conclui que a metamorfose de identidades é parte essencial dos processos de emancipação. As decisões de consumo aparecem nesse caso como alavancas para o processo de mudança, essenciais para que os indivíduos abandonassem suas identidades de vulnerabilidade e se tornassem sujeitos ativos na construção de suas próprias trajetórias.

O livro De refém a protagonista: consumo, identidade e emancipação, de Sérgio Dantas, é uma contribuição importante para o campo de estudos do consumo, principalmente em sua articulação com a identidade, por analisar as escolhas de consumo como parte integrante do processo de formação de identidades e de autonomia dos indivíduos, pensando esse ato distanciado de uma visão utilitarista. A obra entende o ato de consumir como possibilidade de apoio para indivíduos que desejam transformar sua realidade e se emancipar das condições de identidade que lhes foram atribuídas pelo sistema, principalmente no que tange à 
transformação de identidades vulneráveis em autônomas. Nas palavras do próprio autor: 'se, por um lado, ‘ter' não basta para 'ser', por outro, vemos que o 'ter' pode colaborar - ou até mesmo ser condição - para um 'ser’ mais autônomo” (DANTAS, 2015, p. 198). 